Article

\title{
Reviving the Dead: A Kierkegaardian Turn from the Self-Positing to the Theological Self
}

\author{
Amber Bowen 1,2 \\ 1 Trinity College Bristol, University of Aberdeen, Aberdeen AB24 3FX, UK; r02alb17@abdn.ac.uk \\ 2 Hong Kierkegaard Library, Northfield, MN 55057, USA
}

Received: 17 September 2019; Accepted: 24 October 2019; Published: 15 November 2019

\begin{abstract}
Kierkegaard scholars have traditionally chosen to read Kierkegaard as either a theologian or a philosopher. As a result, his corpus is bifurcated as theologians and philosophers lean on their preferred texts. Beneath this practice is an underlying assumption that philosophy and theology "make two," or should be kept in separate corners. However, a contemporary movement in philosophy known as New Phenomenology has challenged this dualistic maxim and instead finds it appropriate for phenomenology to draw from a theological archive. This article suggests that the possibilities New Phenomenology makes available help us retroactively better understand Kierkegaard's text, Sickness unto Death. Fictional author, Anti-Climacus uses theology strategically to open up J. G. Fichte's ontological monism and to move constructively beyond the dead end of his philosophy. Sickness unto Death effectively demonstrates New Phenomenologist, Emmanuel Falque's claim that the more we theologize, the better we philosophize.
\end{abstract}

Keywords: Kierkegaard; Fichte; sickness unto death; new phenomenology; Emanuel Falque; theology; philosophy; idealism; theological self; monism; infinite qualitative difference; phenomenology

For some, Kierkegaard is a philosopher. For others, he is a religious thinker. The choice between the philosophical and the theological Kierkegaard is often presented as an either/or, and scholars entering the gates of Kierkegaardian studies must take sides. As a consequence of this absolute choice between the philosophical or the theological Kierkegaard, observes John Elrod, scholars tend to pull his texts in opposing directions. ${ }^{1}$ Theologians typically rely on Practice in Christianity and the Upbuilding Discourses, while philosophers gravitate to Either/Or and The Concept of Anxiety. The readiness to bifurcate the Dane's corpus is a product of a broader judgment about the relationship between philosophy and theology - to wit, that they are incompatible and should be resigned to separate corners.

A group of contemporary French philosophers known as New Phenomenologists ${ }^{2}$ are rightly calling into question the opposition between philosophy and theology. They seek to employ the methodological tools of both phenomenology and theology to explore areas of human experience that are out of classical phenomenology's reach, namely, religious experience. New Phenomenologists are convinced that the practice of bracketing the transcendent allows phenomenology's exploration of human experience to go only so far. ${ }^{3}$ Instead, they think it entirely appropriate to draw from a theological archive in order to give phenomenology's insights longer reach and broader import. New

\footnotetext{
(Elrod 1975, p. 14).

Included in this group are Michel Henry (1922-2002), Jean-Luc Marion (1946-), Jean-Louis Chrétien (1952-), Jean-Yves Lacoste (1953-), and Emmanuel Falque (1963-).

3 (Falque 2016, p. 21). Falque calls this technique a "counterblow" to philosophy by theology, but this concept deserves some clarification. A counterblow is designed to overpower and defeat an opponent, which is not what New Phenomenologists attempt to do to philosophy. They seek to breach the closed walls of philosophy for its benefit, not its demise. Falque imagines a counterblow to be a loving struggle, much like an athletic competition, whereby both philosophy and theology
} 
Phenomenology's aim is to create a condition in which the two disciplines are no longer isolated but are used together for their mutual enrichment.

In light of this exciting enterprise, it is worth asking if such a project could be used retroactively to better understand Kierkegaard. Is it possible that a strong interpretation of the "philosophy and theology make two" ${ }^{\prime 4}$ maxim generates an interpretive grid that has hidden more than it has revealed in the Dane's body of work? Better yet, could the Kierkegaardian corpus itself demonstrate a mutually beneficial interaction between the disciplines without collapsing their distinctiveness? ${ }^{5}$ To begin answering these questions, this essay explores Kierkegaard's text, Sickness unto Death (SUD) (Kierkegaard 1983), particularly attending to the way the pseudonymous author, Anti-Climacus, uses theology strategically to open up J. G. Fichte's ontological monism and move constructively beyond the dead end of his philosophy.

SUD is an ideal choice for a meta-philosophical analysis for three reasons. First, it is a single text that contains strong theological and philosophical elements. Bifurcating the Kierkegaardian corpus is hermeneutically suspect enough. What does one do with a single text that cannot easily be classifiable as one or the other? SUD thus forces the reader to grapple with the loving struggle between the two disciplines. Second, SUD does not conflate theology and philosophy, but distinguishes them in its content and by its structure. It can therefore offer a valuable contribution to the current debate on how to relate the two disciplines in a mutually beneficial way. Third, a meta-philosophical analysis of SUD requires an extensive investigation of Kierkegaard's interaction with the thought of Fichte. While there is much discussion on the relationship between Kierkegaard and Hegel, there is far less on the Dane's interaction with Fichte, a figure who was just as much a fixture in his philosophical context. This essay provides an overview of the relevant features of Fichte's thought regarding the self and then lays out how Anti-Climacus uses theology as a strategic response. SUD effectively demonstrates that, while there is a sense in which theology and philosophy do "make two," it is also true that the more we theologize, the better we philosophize. ${ }^{6}$

\section{The Conversation}

To see the brilliance of the Kierkegaardian strategy, it is important to become acquainted with his philosophical context. Kierkegaard's relationship to his predecessors is a peculiar one. While he shares essential concepts, concerns, and ideas from the Idealist tradition that strongly influence the direction

engage one another with passion and intensity in order to strengthen both. This approach, Falque says, "defines another and a new relationship between philosophy and theology with careful attention to the conjunction-and-rather than to their disjunction - or — as is most often practiced today." (Falque 2016, p. 18). The endeavor is not to collapse the two disciplines into one, nor is it to transition from one to the other. Rather, New Phenomenologists imagine how the two disciplines fruitfully relate and benefit each other.

4 This slogan is originally coined by Dominique Janicaud in his infamous essay critiquing New Phenomenology. He intends it to mean that philosophy and theology are entirely incommensurable and should have nothing to do with one another on principal. Though he does not discount theology as a discipline, he believes that theological content would be a contaminant to philosophical, specifically phenomenological, rigor. Therefore, a wall of division should be maintained in order to protect the purity of both. See Dominique Janicaud, "The Theological Turn of French Phenomenology," in (Janicaud 2000, p. 99). J. Aaron Simmons and Bruce Ellis Benson offer a softer interpretation of this maxim, suggesting that while the disciplines should remain distinct as unique professional discursive communities, it is possible-even beneficial—to share resources under certain conditions. See (Simmons and Benson 2013). This essay suggests Kierkegaard's text, (Kierkegaard 1983) models the softer interpretation.

5 It is important to note that the relationship between philosophy and theology is intensely debated even among New Phenomenologists. While they minimally agree that the two are not incompatible and that it is acceptable for philosophy to draw from a theological archive, some, such as Jean-Luc Marion, maintain a strong disciplinary boundary between the two. Others, like Emmanuel Falque and Jean-Yves Lacoste, would like to dissolve the distinction between the two altogether. In fact, Jean-Yves Lacoste looks to Kierkegaard to legitimize this approach, arguing that the Dane models what happens when conventional disciplinary boundaries disappear and "nothing, then, remains of the gap between the object of reason and the object of belief, which is to say, between what is exclusively open to reason and exclusively open to belief." (Lacoste 2018, p. 71). Lacoste represents the opposite end of the spectrum in the debate on the relationship between philosophy and theology, and his own stance on the matter becomes a hermeneutical grid through which he approaches the Kierkegaardian texts.

6 (Falque 2016, p. 25). 
of his own thinking, his thought is equally shaped by critical reaction to that tradition. ${ }^{7}$ As Hün and Schab note, "Kierkegaard's polemic against idealism is not to be read as a purely immanent critique within a shared horizon that might allow for a relative justification of aspects of his predecessors' work. Instead, its ex negative points us towards Kierkegaard's own intellectual agenda and can be understood only in relation to this." ${ }^{8}$ Hün and Schab suggest that Kierkegaard's relationship with the German Idealists is best considered a "twofold tension between productive appropriation and critical distance." ${ }^{\prime 9}$ By their assessment, Kierkegaard pillages what he finds useful while also distinguishing himself from the tradition as a whole. While this explanation has been traditionally satisfactory, it is likely he was doing something far more insightful and tactical than pillaging and burning. In Sickness unto Death, for example, Kierkegaard's pseudonymous author, Anti-Climacus, puts the "loving struggle" between philosophy and theology on full display.

\section{Fichte's Original Insight}

Fichte, the founder of German Idealism, offered his work as a response to Kant. ${ }^{10}$ Both Fichte and Kant consider self-consciousness not simply an area of philosophical interest, but the essential starting point for all philosophical inquiry. However, Fichte approaches the structures of consciousness in a different way. Kant's model, which Fichte calls "dogmatism," suggests that things-in-themselves exist in a mind-independent, external world. These external objects are then represented inside the inner chamber of the human mind. Because of the gulf between the inner chamber of the mind and external reality, the mind cannot directly access things-in-themselves (the noumena) but can only perceive the way things appear (the phenomena). ${ }^{11}$ Fichte is concerned about dogmatism for two reasons. First, the dogmatic self is unable to be aware of itself as a subject and is thus never able to achieve self-consciousness. ${ }^{12}$ The Kantian self, for example, looks at itself from an external standpoint just like it would any other object, but examining itself as an object is different from indwelling oneself as a subject. Self-consciousness, he says, is immediate knowledge of oneself as oneself.

Second, Fichte fears dogmatism will lead to a materialist view of the self. Materialism, now referred to as physicalism, suggests that everything, including consciousness, can be explained in relationship to matter. Fichte refuses the idea that self-consciousness can be reduced to physical events and processes because the self would be determined by the outside world rather than its own agency. Rather than becoming an assertive subject, he fears the dogmatic self will become a product of its environment. He prefers instead to give an account for the possibility of a moral being that exercises autonomous self-limitation.

Fichte counter-proposes what he considers the only alternative to dogmatism: Idealism. Rather than the self seeking to access itself and things-in-themselves through external reality, all of reality, he

7 Beyond his master's thesis, The Concept of Anxiety, Kierkegaard's authorship rarely references German Idealist philosophers by name. Nonetheless, Hün and Schwab argue that Kierkegaard "addresses idealist positions in the context of his own thought projects. And even when he does this, it is often with the aim of sharpening and clarifying his own approach by differentiating it from that of idealism." (Hün and Schwab 2013, p. 64). Consistent with his method of indirect communication, throughout his authorship Kierkegaard and his pseudonyms make reference to specific concepts and even authors without directly addressing them by name.

8 See (Hün and Schwab 2013, p. 62). David J. Kangas comes to the same conclusion specifically regarding Kierkegaard's relationship to Fichte. By his assessment, Kierkegaard both appropriates and distances himself from Fichte's thought. (Kangas 2007, pp. 67-95).

9 Hün and Schwab 2013, p. 62).

10 For a deeper discussion, see (Beiser 1987) and (Henrich 2003).

11 (Lumsden 2014, p. 41). Lumsden explains, "Dogmatism is a very broad rubric for Fichte, under which much of the philosophical tradition lies; it includes Spinozism, naturalism, and realism. In summary, he takes dogmatic philosophy as offering causal explanations... As Fichte sees it, causal explanations, for example of consciousness and the intellect, present them as caused by something other ... [this] reduces knowing and experience to a deterministic relation that negates human freedom ... since the consistent dogmatist would have to reject the independence of the I, characterizing it as just another thing" (41).

12 See (Lumsden 2014), Hegel, Heidegger, and the Post-Structuralists, p. 43. 
suggests, is encompassed in the Absolute Self. ${ }^{13}$ Things that appear to be outside of the self are actually confined within it and generated by it. Rather than observing itself from outside of consciousness, the idealist self is always aware of itself from within consciousness. Knowledge does not come through mediated representation, but all knowledge is self-knowledge. Fichte thus proposes an original theory of the self that is based on three fundamental principles: (1) The Absolute Self is posited by itself; (2) The Absolute Self also posits the non-self, which is in opposition to the self; and (3) the self and the non-self limit each other and create a condition of finitude. It is important to briefly overview these principles of the Fichtean self in order to recognize the strategic genius of the Kierkegaardian self in Sickness unto Death.

Fichte's first principle is as follows: The Absolute Self posits itself. To explain, he appeals to the law of identity, according to which, "there is a necessary connection between the two that is posited absolutely, and without any other ground." 14 He continues:

[The] above proposition can also be expressed as follows: if A is posited in the self, it is thereby posited, or, it thereby is. Thus the self asserts, by means of $\mathrm{X}$, that $A$ exists absolutely for the judging self, and that simply in virtue of its being posited in the self as such; which is to say, it is asserted that within the self-whether it be specifically positing, or judging, or whatever it may be-there is something that is permanently uniform, forever one and the same; and hence the $\mathrm{X}$ that is absolutely posited can also be expressed as I = I, I am I. ${ }^{15}$

For Fichte, this abstract logical principle of identity is not the first principle of philosophy, but merely a preliminary "clue" for a far more fundamental truth: $\mathrm{I}=\mathrm{I}$. According to "I $=\mathrm{I}$," the $\mathrm{I}-\mathrm{or}$ the self-is posited, or put into being, by itself. It exists absolutely by and for its own assertion. ${ }^{16}$ According to this principle, the self is not called into existence by Another, but it issues forth its own summons. The conscious subject does not observe itself as an object, but it is immediately aware of itself. ${ }^{17}$ The self is its own creator and has no outside determining factors or influences. Everything is encompassed within itself: there is no outside. Therefore, he writes, "As [the self] posits itself, so it $i s ;$ and as it is, so it posits itself; and hence the self is absolute and necessary for the self." ${ }^{18}$ In short, self-consciousness both constitutes and contains being.

Fichte's paradigm of radical immanence seems to be an easy solution to the Kantian problems of (1) the self not being able to establish subjectivity, and (2) collapsing into a mechanistic view of the self being devoid of agency. However, Fichte recognizes a problem of his own. The only way for the self to recognize itself as a self is if it encounters what is different from it. The self must meet the non-self.

13 There has been a resurgence of interest in Fichte's thought in recent years as scholars found his texts to be relevant for contemporary issues in epistemology, philosophy of mind, and theory of action. Fichte has been traditionally read as a radical solipsist. For an example of this kind of reading, see (Copleston 1965). Henrich paved the way for an alternative reading of Fichte that provides a non-naturalistic view of the self. See (Henrich 2003). Some have arguably overdrawn on Fichte as a resource for contemporary issues at the expense of reading him anachronistically. (Martin 1997) and (Pippin 2000) argue that Fichte's idealism makes only epistemological claims rather than metaphysical ones. They suggest he critiques dogmatism for making metaphysical claims about the existence of things-in-themselves and instead prefers to talk about the intentionality of mental states. While this reading, as (Hicky 2004), does draw fresh attention to Fichte's project, it misreads Fichte's clear metaphysical assertions.

14 (Fichte 1982, p. 95).

15 (Fichte 1982, pp. 95-96).

16 Fichte explains that the formula $\mathrm{A}=\mathrm{A}$ is conditional: if $\mathrm{A}$ exists then it is $\mathrm{A}$. In contrast, the first principle $\mathrm{I}=\mathrm{I}$ is an unconditional statement. There is no hypothetical "if" when it comes to the existence of the I. It exists unconditionally and its identity is tied to its unconditional existence. (Fichte 1982, p. 96).

17 See (Neuhouser 1990, p. 83). He explains, "[Fichte's] subject is to be understood not as a mere fact, a Tatsache, but as a Tathandlung, a 'Fact-act.' In creating this new term for the subject Fichte starts with the word Tatsache, but replaces Sache ('thing') with Handlung ('act'), thereby expressing what will become the central point of his theory of the subject: The I is not to be understood as a thing but as an activity. Furthermore, the subject is a 'Tat'-handlung, an activity that is at the same time a deed, or fact. The point of joining Tat with Handlung to coin a new term for the subject is to suggest that the existence of the $\mathrm{I}$, its facticity, stands in some intimate relation to its activity and, further, that it is this relation that essentially distinguishes a subject from a thing." (Neuhouser 1990, p. 106).

18 (Fichte 1982, p. 98) 
But, if reality is the indeterminate, undifferentiated Absolute Self, how can there be a non-self? Under a monist paradigm, how is any kind of differentiation possible? Fichte's solution is asserted in his second principle: the Absolute Self also posits the non-self, which is in opposition to the self. In other words, the self posits itself and also the non-self. He explains, "Every opposite, so far as it is so, is so absolutely, by virtue of an act of the self, and for no other reason. Opposition in general is posited absolutely by the self. If any A is to be posited, an A must be posited."19 The non-self is a relation of opposition created by the Absolute Self. This principle is Fichte's attempt to preserve his concept of the Absolute Self while also accounting for the existence of a non-self.

Unfortunately, the second principle's solution generates another problem. Would not the self and the non-self be a threat to one another? Would not one seek to overcome the other? In other words, does not the second principle destroy the first principle? ${ }^{20}$ While it is true that the second principle stands in opposition to the first, Fichte's concept of the self is based on dialectical logic. His first principle, that the self posits itself, is a thesis. His second principle, that the self posits the non-self, is an antithesis, or an opposition of the thesis. The thesis and the antithesis eventually give way to a synthesis. This synthesis is Fichte's third principle: The self and the non-self will mutually limit one another, creating the finite self. According to this third principle, the self limits the non-self so it does not overpower the self, and the non-self limits the self so it does not annihilate the non-self. Fichte clarifies, "To limit something is to abolish its reality, not wholly but in part only, by negation. Thus, apart from reality and negation, the notion of a limit also contains that of divisibility (the capacity for quantity in general, not any determinate quantity) ..." ${ }^{\prime 21}$ When the self is limited by the non-self, it becomes finite, or a manifestation of the Absolute Self. Differentiation reveals what the self is and what it is not. It gives it certain characteristics and does not give it others. As Henrich says, "The self has to limit itself; and such limiting is possible only if it excludes something from itself and attributes to the not-self what is excluded from the self ..."22 Even in its own limitation, the Absolute Self is absolutely determinate. It alone draws the lines of division between the self and the non-self that create the finite self. Thus, the self decides both "that" it exists and also the kind of person it will be. ${ }^{23}$ According to Beiser, the Fichtean self "acts according to its own concept of itself, that it becomes only what it conceives itself to be, so that its essence or nature conforms entirely to its own rational choice." ${ }^{24}$ In contrast to dogmatism, Fichte says it is not the self's objectivity that leads to its subjectivity, but the self's absolute subjectivity that establishes its objectivity, or the finite version of itself. He believes the only way a self can become a true subject is if it is entirely self-determined; and self-determination is only possible if the self is not grounded by or related to anything—or Anyone—external to itself.

\section{Fichte's Border}

In order to establish a radically autonomous, self-positing self, Fichte creates a fixed border between philosophy and theology. In his short essay, "On the Foundation of Our Belief in a Divine Government," Fichte orders philosophers to remain in their domain:

Where now will the philosopher, who presupposes belief in God, search for the necessary ground which he is supposed to furnish? Should he base himself on the alleged necessity with which the existence of the nature of the world of the senses implies a rational author? The answer must be an emphatic "no." For he knows only too well that such an inference is totally

\footnotetext{
(Fichte 1982, p. 103).

(Fichte 1982, p. 106).

(Fichte 1982, p. 108).

(Henrich 2003, p. 210).

3 (Neuhouser 1990, p. 170).

4 (Beiser 2008, p. 277). It is worth noting that Fichte's account of self-determination anticipates later atheistic existentialist articulations of radical freedom. Kierkegaard's critique of complete self-determination demonstrates not only his critical distance to German Idealism, but also the lack of resemblance between Kierkegaard and existentialist philosophers such as Sartre and DeBeauvoir. It is Fichte, not Kierkegaard, who seems to be the father of their thought on freedom.
} 
unwarranted, although misguided thinkers have made such a claim in their embarrassment to explain something whose existence they cannot deny but whose true ground is hidden from them. The original understanding, which is placed under the guardianship of reason and the direction of its mechanism, is incapable of such a step. One may regard the world of the senses either from the point of view of commonsense which is also that of the natural sciences or else from the transcendental standpoint. In the former case reason is required to stop at the existence of the world as something absolute: the world exists simply because it does and it is the way it is simply because it is that way ... From this point of view, the world is an organized and organizing whole containing the ground of all phenomena within itself and its immanent laws. If, while occupying the standpoint of the pure natural sciences, we demand an explanation of the existence and nature of the universe in terms of an intelligent cause, our demand is total nonsense. ${ }^{25}$

According to Fichte, engaging religious ideas, concerns, or content push philosophy beyond its limits into absurdity. Of course, he continues, "It may be admitted that these difficulties vanish if we adopt the transcendental standpoint. There is then no longer an independent world: everything is now simply a reflection of our inner activity." ${ }^{26}$ In other words, not only should philosophy and religion be kept in separate corners, but philosophy makes religion obsolete. Religion is "not really an intelligible pronouncement and what we get are a few empty words instead of a genuine answer to a question that should not have been raised in the first place." ${ }^{27}$ God-talk is empty because it is nothing more than a projection from the Absolute Self. In a letter to Jacobi, Fichte writes:

From [the practical point of view] there is a world that exists independently of us, which we can only modify; from [this point of view] the pure I, which does not completely vanish even for this point of view, is posited outside of us and called God. How else could we have arrived at the properties that we ascribe to God and deny of ourselves if we had not found them in ourselves and then only denied them of ourselves in a certain respect (as individuals)? ${ }^{28}$

Just as it does with any non-self, the Absolute Self posits God. It ascribes special qualities and abilities to God as part of its normal process of distinction between the self and the non-self. The self then differentiates its own abilities and limitations against the backdrop of the characteristics it gives to God. In short, God is a concept that exists for the self's own self-definition. According to this theory, theology does not confront philosophy but is swallowed up by philosophy and rendered obsolete.

\section{Fichte's Dead End}

While Fichte's theory is indeed "original," it leads to a philosophical dead end. According to Loncar:

Fichte's account of the self, though striking and original, raises a question that would vex him for the duration of his philosophical career: if the self posits the I, yet also posits the I as limited by the not-I, how is the self able to posit itself, especially since its "self" is necessarily in a relationship with the not-self? Though this question applies generally to Fichte's account of the I-world relationship, it also applies to his account of self-consciousness. The basic problem is that consciousness is a unity of the subject-object relationship, and this relationship is somehow constitutive of, yet posited by, itself. ${ }^{29}$

\footnotetext{
(Fichte 1969, p. 21).

(Fichte 1982, p. 21).

(Fichte 1982, p. 21).

(Fichte 1993, p. 411).

(Loncar 2011, p. 206).
} 
For monist paradigms, there is always a problem of relation. Fichte himself recognizes the importance of relation between contrasts in order for the self to recognize itself as a self. He seeks to account for this possibility in his second and third principles without letting go of his monism. However, the attempt to account for difference within an absolute unity is, at best, an uneasy solution. How could a self that posits its own non-self authentically encounter the other since the other is nothing more than its own creation? How could it simultaneously posit itself and the non-self since the non-self is necessary for the positing of the self? Furthermore, how would a finite self relate to the Absolute Self? Fichte describes the self as inherently relational, and yet relating is impossible when all is contained within the Absolute Self.

Historically, Fichte's fundamental principles were met with harsh criticism and even ridicule by his contemporaries who wondered how his wife could tolerate a man who imagined reality as a projection of his absolute subjectivity. When a group of enraged students raided and vandalized Fichte's house, Goethe pointed out the unfortunate irony of the situation; it was, after all, a forceful demonstration of the non-ego's existence. ${ }^{30}$ Breazeale continues:

For Fichte, 1799 was a year filled with disappointment. Not only did he lose his job, but he also began to lose many of his most prominent philosophical allies, including Reinhold, who had briefly become an enthusiastic exponent of the Wissenschaftslehere. Schelling, the most conspicuous and prolific of the young "Fichteans," continued, despite Fichte's disapproval, to pursue his interest in "the philosophy of nature," while Jacobi, whom, for all their philosophical difference, Fichte greatly admired, published a long Open Letter to Fichte, in which he devastatingly characterized the Wissenschaftslehere as "nihilism." Finally, in August 1799, Kant himself issued a public "declaration" in which he repudiated Fichte's system and disavowed any relationship between his own philosophy and the Wissenschaftslehre. ${ }^{31}$

For the next decade, Fichte continued to revise and even redraft the principles of his system, eventually concluding that "he himself was simply incapable of producing a written exposition of his own philosophy which could stand on its own and avert the sorts of misunderstanding to which his Jena writings had been subject." 32 Though his influence is undoubtedly pervasive, Fichte died with a project that could go no further.

\section{How to Revive the Dead}

Where Fichte dead-ends, Kierkegaard's authorship begins. German Idealism was the air Kierkegaard breathed both in Copenhagen, where he lived, and in Berlin, where he studied. ${ }^{33}$ Thus, says Kangas, "Fichte may very well be the most overlooked resource for Kierkegaard's thought. Arguably, Fichte is as important as Hegel and more important than Kant in shaping the contours of Kierkegaard's thought." ${ }^{\prime 34}$ Kierkegaard's interaction with Fichte's thought is most evident in his work, The Sickness unto Death (Kierkegaard 1983), written by pseudonymous author, Anti-Climacus. In it, Anti-Climacus continues Fichte's conversation on the self while also breaking through his philosophical impasse. Anti-Climacus undertakes a two-part tactic to rescue the Fichtean self. In part one, he turns Fichte's three fundamental principles on their heads. Second, he suggests an alternate criterion for true self-hood. In part one, the author draws from the tools of philosophy, or that which is available to human understanding, to make his case. In part two, Anti-Climacus deepens the account of the self he established in part one, this time drawing from the tools of revealed theology. Parts one and

(Schaub 1912, p. 568).

(Breazeale 1993, p. 145).

32 (Breazeale 1993, p. 146). As stated earlier, recent scholarship has sought to exonerate Fichte's work by offering better readings than those of his contemporaries, however, the aim of this essay is not to engage with contemporary uses of Fichte's thought, but to focus on Kierkegaard's strategic movement in relation to it as a precedent for contemporary discourse.

33 (Loncar 2011, p. 207).

34 (Kangas 2007, p. 67). 
two together stage a rescue of the Fichtean self and model a fruitful relationship between philosophy and theology.

\section{A Twist}

Readers familiar with Fichte's three foundational principles will recognize that Anti-Climacus begins his work with a formula that initially echoes some of Fichte's own language, but with a surprising twist at the end. He writes:

A human being is spirit. But what is spirit? Spirit is the self. But what is the self? The self is a relation that relates itself to itself or is the relation's relating itself to itself in the relation; the self is not the relation but is the relation's relating itself to itself. A human being is a synthesis of the infinite and the finite, of the temporal and the eternal, of freedom and necessity, in short, a synthesis. A synthesis is a relation between two. Considered in this way, a human being is still not a self. ${ }^{35}$

Anti-Climacus agrees with Fichte that the self is fundamentally relational and that self-consciousness arises through a dynamic relation within the self. He explains that the self has three levels of relationality. The first level consists in a harmonious interplay between binary opposites within the self: infinite/finite, temporal/eternal, freedom/necessity. The opposing elements are not combined like ingredients in a cake, neither do they work like two different parts in a machine. Rather, their distinctiveness facilitates a relational dynamic between the two that unfolds more like a dance than a turning gear. The self's finitude, temporality, and necessity ground it in the world as a concrete being, while its infinitude, eternality, and freedom allow it to reach beyond its concrete limitations to grow and expand. When the opposites relate properly, the human self is neither worldless nor determined. It is limited by the world without being limited to it.

According to Anti-Climacus's formula, the first-order relation, the interplay between the binaries, gives rise to the second-order relation he calls "spirit." The Kierkegaardian notion of spirit is analogous to what other philosophers like Fichte refer to as "self consciousness," an awareness of the self as a self. Fichte says the Absolute Self is self-consciousness, but Anti-Climacus begs to differ. Self-consciousness is simply the self's awareness of itself as a self, not the experience of robust self-hood. There is yet another, more fundamental relation that allows the self to become a true self. He says:

Such a relation that relates itself to itself, a self, must either have established itself or have been established by another. If the relation that relates itself to itself has been established by another, then the relation is indeed the third, but this relation, the third, is yet again a relation and relates itself to that which established the entire relation. The human self is such a derived, established relation, a relation that relates itself to itself and in relating itself to itself relates itself to another. ${ }^{36}$

Here Anti-Climacus submits that the self must have either posited itself, as Fichte claims, or it must be posited by another. Both agree that the self must encounter the non-self in order to recognize itself as a self. However, while Fichte believes the non-self is posited by the Absolute Self, Anti-Climacus argues that the self is posited by the Absolute Non-Self. Thus, the true self is not the Absolute Self that relates only to itself, but one that "rests transparently in the power that established it." ${ }^{37}$ As part one progresses, Anti-Climacus refers to this external power as "God." At this point, he gives no determinative content to the word "God," but merely uses it to refer to some sort of external establishing power. ${ }^{38}$

\footnotetext{
(Kierkegaard 1983, p. 13).

(Kierkegaard 1983, pp. 13-14).

(Kierkegaard 1983, p. 14).

38 The reference to God in part one is open enough that some scholars conclude it does not require a theological interpretation in a dogmatic sense. For an example of this line of reasoning, see (Lundsgaard-Leth 2018). Another a-theological reading
} 
Rather than allowing these opposites of finitude/infinitude, temporality/eternity, and necessity/freedom to exist in a both/and relationship, the self sometimes turns the binary opposites into an either/or, choosing one side to overpower the other. One element then annihilates its opposite by transcending the space of difference that lies between the two. For a relational self, such a move is detrimental. It takes two different elements to form a relation. Therefore, if one element dominates the other, a proper first-order relation is no longer possible.

The three levels of relation that make up the Kierkegaardian self do not exist independently of one another. A distorted first-order relation will inevitably lead to a distorted second-order relation, causing the self to feel alienated from itself. Yet, the disorder does not stop there, because an imbalance in the self is never isolated. A mis-relation in one relation always indicates a mis-relation in the other two. While despair often presents itself as a mis-relation between the internal first and second order relations, according to Anti-Climacus's formula, it is always connected to a mis-relation between the self and God. ${ }^{39}$ To overcome despair, the self needs to do more than try to re-sync its internal binaries. It must face the brokenness in its relationship with God.

While there are different forms of despair, they can all be traced back to a desire for self-mastery. Whether the self refuses to be a self at all (weak despair) or whether it insists on being a certain kind of self (defiant despair), the essential feature of both forms is the assertion of the self's own will over and against its establishing power. ${ }^{40}$ Thus, despair signals the self's refusal to relate rightly to its establishing power, choosing instead to operate as though it were its own establishing power. As Anti-Climacus masterfully articulates:

And this is the self that a person in despair wills to be, severing the self from any relation to a power that has established it, or severing it from the idea that there is such a power. With the help of this infinite form, the self in despair wants to be master of itself or to create itself, to make his self into the self he wants to be, to determine what he will have or not have in his concrete self. His concrete self or his concretion certainly has necessity and limitations, is this very specific being with these natural capacities, predispositions, etc. in this specific concretion of relations, etc. But with the help of the infinite form, the negative self, he wants first of all to take upon himself the transformation of all this in order to fashion out of it a self such as he wants, produced with the help of the infinite form of the negative self-and in this way he wills himself. In other words, he wants to begin a little earlier than do other men, not at and with the beginning, but "in the beginning." 41

Rather than securing the self's freedom and autonomy, Anti-Climacus says attempting to be one's own establishing power leads to its death—or worse, sickness unto death, which is the state of wanting to die without being able to:

[Despair] is veritably a self-consuming, but an impotent self-consuming that cannot do what it wants to do. What it wants to do is consume itself, something it cannot do, and this impotence is a new form of self-consuming, in which despair is once again unable to do what it wants to do, to consume itself ... This comfort is precisely the torment, is precisely

of SUD focusing on the content of part one comes from (Klee 2017). For both, "God" as the establishing power of the Kierkegaardian self in part one can mean a vague relation to the infinite that exceeds it or to the self's own ideals or projects. What these authors get right is that the notion of God in part one does not carry much determinative content at all. Stopping at the end of part one may allow the reader to fill in the notion of God with whatever she wants it to be, but at the cost of bifurcating a singular text and interrupting the author's progression of thought halfway.

39 (Kierkegaard 1983, pp. 29-30).

40 Anti-Climacus explains that though he identifies two forms of despair they are related. Speaking of weak despair, he writes, "To call this form of despair in weakness already casts a reflection on the second form, in despair to will to be oneself. Thus, the opposites are only relative. No despair is entirely free of defiance; indeed, the very phrase 'not to will to be' implies defiance. On the other hand, even despair's most extreme defiance is never really free of some weakness. So the distinction is only relative." (Kierkegaard 1983, p. 49).

41 (Kierkegaard 1983, p. 68). 
what keeps the gnawing alive and keeps life in the gnawing, for it is precisely over this that he despairs (not as having despaired): that he cannot consume himself, cannot get rid of himself, cannot reduce himself to nothing. ${ }^{42}$

Considering Anti-Climacus's notion of the sickness unto death in connection to Fichte is especially interesting. The self that carries on as though it were a self-posited being is in a state of either weak or defiant despair, whether it is conscious of being in this state or not. Yet even in its despair, the self cannot do what it wants to do. It cannot consume itself. In other words, when the self finds it cannot achieve its own self-creating, it desires to put an end to itself, or to de-create itself by reducing itself to nothing. Yet it never succeeds. Why? The most obvious answer is that it fails to end itself because it was not the One who made itself out of nothing in the first place. It is not the establishing power, so its attempts to wipe clean the slate of its existence and start over are fruitless. If the Fichtean theory were true, then the self would experience despair differently. As Anti-Climacus says, "If the human self had itself established itself, then there could only be one form [of despair]: not to will to be oneself, to will to do away with oneself, but there could not be the form: in despair to will to be oneself." Put differently, if the self were self-positing, it could certainly conclude that it does not like the way it has turned out. In that case, it would have the prerogative either to remain in a shallow, spiritless existence or to un-posit and re-posit itself into whatever form it wished. In other words, a self-positing self could resolve despair on its own. However, the self does not have this prerogative since it cannot reduce itself to nothing no matter how hard it tries. Thus, the experience of sickness unto death-or the will to die but the inability to do so-is the strongest evidence that the self cannot be a self-positing being.

At the end of part one, Anti-Climacus observes that even when the self recognizes it is not self-authored, it may still respond with defiance, preferring to shake its fists at its establishing power rather than become a true self by resting transparently in it. He writes:

Just as the weak, despairing person is unwilling to hear anything about any consolation eternity has for him, so a person in [defiant] despair does not want to hear anything about it either, but for a different reason: this very consolation would be his undoing-as a denunciation of all existence. Figuratively speaking, it is as if an error slipped into an author's writing and the error became conscious it itself as an error-perhaps it actually was not a mistake but in a much higher sense an essential part of the whole production-and now this error wants to mutiny against the author, out of hatred toward him, forbidding him to correct it and in maniacal defiance saying to him: No, I refuse to be erased; I will stand as a witness against you, a witness that you are a second-rate author. ${ }^{43}$

Here again, Anti-Climacus shows how the experience of the sickness unto death destroys the self's illusion of self-mastery. The height of the sickness unto death is when the self is conscious of the truth about itself and yet refuses to be cured.

\section{The Method behind the Move}

Notice how Anti-Climacus approaches this discussion. He could toss out an alternative theory to the Fichtean self and back it up through logical proofs or metaphysical reasoning. He chooses instead to challenge the idealist notion of the self by offering a robust description of how humans experience despair, one that considers both the apparent and unapparent dimensions of that experience. There is more to this method than a purely existential analysis of an emotional state or a study of despair as a psychological condition. Rather, this kind of analysis is decisively phenomenological. ${ }^{44}$ Agreeing that Kierkegaard's texts should be read in this way, Come writes:

42 (Kierkegaard 1983, pp. 18-19).

43 (Kierkegaard 1983, p. 74).

44 There has been some attention given to the question of whether Kierkegaard can be considered a type of phenomenologist. See (Hanson 2010). The authors in Hanson's volume largely agree that he shares similar concerns, themes, and approaches 
What I mean when I say that his basic method is phenomenological can be stated simply: he begins his every exploration of human existence with an analysis of his own self, his own experience, whether the topic is sin, anxiety, despair, faith, love or God. And his goal, his ending is not a system of ideas or even understanding but is to turn his "subjective reflection" toward the task of transformation of his concrete existence as a self.

Come further suggests that any categories or concepts in Kierkegaard's authorship forward are always "subject to the control and correction of the phenomenological." 45 Anti-Climacus's approach is a perfect example of this method. He undoubtedly considers tri-relationality to be a universal structure of the self, but he takes a phenomenological route to arrive at this conclusion. The phenomenon of despair initially discloses the self to itself as a contingent rather than an autonomous being. To be sure, some selves are aware of their despair and others are not. ${ }^{46}$ However, this lack of awareness proves that despair is a phenomenon with "forms of hiddenness and absence [that] are essential to [its] makeup ..." ${ }^{\prime 47}$ By attending to the phenomenon of despair, the self sees the structures of its consciousness more clearly. It recognizes itself as a dependent being who is infinitely qualitatively different from the power that established it.

\section{A Switch}

After turning Fichte's foundational principles on their head, breaking open his monism through a phenomenological analysis of despair, Anti-Climacus's second strategic step is to introduce a different criterion for healthy selfhood. "The criterion for the self," he says, "is always: that directly before which it is a self, but this in turn is the definition of 'criterion."'48 A criterion is a standard determining what a thing should be. Something can be measured against its criterion to determine how "true" it is. For Fichte, a self is true or untrue based on how assertive it is to create itself and to project the world around it. In part one, Anti-Climacus submits that there is a relation even more fundamental to the self than its internal relation, namely, its external relation to the power that establishes it, which he also calls "God." Yet, in part two, he takes a closer look at the nature of this relationship as the true criterion for the self, and he gives determinative theological content to his notion of the divine. He additionally recasts despair in theological terms as sin. Deepening his initial description, Anti-Climacus explains that if the self's relationship with God is broken by $\sin$, it will experience the infinite qualitative difference as a space of alienation. However, if the self looks to Christ as the only Mediator of the IQD, it receives forgiveness. The space of difference is no longer an obstacle to its relationship with God but a facilitator of it. It is thus in part two that Anti-Climacus's theological turn is fully executed.

with classical phenomenology even though it would be anachronistic to put him in the Husserlean tradition. While Husserl provides a strict definition of the phenomenological method, (Simmons and Benson 2013) point out that the edges of that definition have been in constant negotiation from the start. Phenomenology has never been a static discipline, but one that continually evolves and expands to be able to explore all areas of human experience. They suggest the figures in phenomenology share more of a family resemblance than a rigid set of doctrines. Kierkegaard obviously did not learn phenomenology from Husserl, but he did learn it from Hegel, who was performing a kind of phenomenological analysis independent of Husserl. The phenomenological tradition, therefore, extends before and beyond Husserl's classical method. If phenomenological analysis, by definition, excludes the transcendent, then Kierkegaard's work is minimally phenomenological. If, however, the new movement known as New Phenomenology is correct, that utilizing the conceptual capital of Christianity does not destroy phenomenology but enhances it, then the kind of phenomenology Kierkegaard practices fits nicely within the broader tradition. The phenomenological nature of Kierkegaard's methods presented by Anti-Climacus in Sickness unto Death is a strong indication that this approach to Kierkegaard's corpus is more than permissible, it is profitable. It uncovers the philosophical depth in his work that would not otherwise come to light. For an insightful phenomenological analysis on despair in SUD and its relation to Hegelian phenomenology, see (Stewart 1997),

"Kierkegaard's phenomenology of despair in Sickness unto Death," Kierkegaard Studies Yearbook 1997 (1997), pp. 117-43.

46 (Come 1998, p. 20)

46 (Kierkegaard 1983, p. 25).

47 Daniel Dahlstrom, "Freedom Through Despair: Kierkegaard's Phenomenological Analysis," in Kierkegaard as Phenomenologist, 75.

48 (Kierkegaard 1983, p. 79). 


\section{Significance of the Structure}

Before looking at the way Anti-Climacus develops his thought in part two, it is important to consider the structure of his text and what it says about the relationship between philosophy and theology. How Anti-Climacus ends part one and how he begins part two happen to fall along the lines of what is accessible to human understanding and what is only accessible through revealed theology. Though he respects what is available to each domain, he is unafraid to transition from philosophy through offense into revealed theology. His aim is not to provide an account of the self that is different from part one, but to deepen his description of what he takes a true self to be. ${ }^{49}$

In part one, Anti-Climacus explores the notion of the human self philosophically by drawing from the tools available to the finite horizon of human understanding. He opens up the German Idealist philosophy of immanence by employing concepts like the necessity of an Absolute Non-Self, the importance of respecting the space of difference between the self and the Absolute Non-Self, the experience of despair, and the notion of a "power" that undergirds the self's existence. Such concepts, including his general notion of "God" as a higher establishing power, are traditionally considered available to Socratic-human understanding apart from revealed theology.

In part two, Anti-Climacus provides a more fully developed description of the self by drawing from the tools of revealed theology. He recasts despair as $\sin .^{50}$ In his opening lines he writes, "Sin is: before God, or with the conception of God, in despair not to will to be oneself, or in despair to will to be oneself." ${ }^{\prime 51}$ The self must recognize that it is not just a self before an Absolute Non-Self, or a finite being contingent on a higher power, but a sinner before God. The self's experience of despair lets it know that it cannot establish itself on its own. Despair confronts the self with the truth that it is not a self-posited being but is posited by a power that is infinitely qualitatively different from it. Through despair, the self even recognizes that its own attempts at self-positing have ultimately failed. Apart from revelation, however, the self cannot know that what it experiences phenomenologically as despair is actually $\sin ^{52}$ Despair is thus a (sac)religious phenomenon that revelation more fully illumines. The resources of philosophy end in part one, but in part two Anti-Climacus uses revelation as an additional tool to further disclose the nature of this phenomenon.

While there are important distinctions in parts one and two, they represent not a sharp division but an intricate strategy. As Anti-Climacus explains in the beginning of part two:

The point is that the previously considered gradation in the consciousness of the self is within the category of the human self, or the self whose criterion is man. But this self takes on a new quality and qualification by being a self directly before God. This self is no longer the merely human self but is what I, hoping not to be misinterpreted, would call the theological self, the self directly before God. And what infinite reality the self gains by being conscious of existing before God, by becoming a human self whose criterion is God! 53

(Grøn 1997, pp. 35-50) challenges readings that too sharply distinguish the self presented in parts one and two. He disagrees with the idea that part one presents a philosophical self and part two a theological self because of the fact that Anti-Climacus makes reference to God as an establishing power of the self in part one. Therefore, argues Grøn, the self described in part one is open to the transcendent and should be designated as theological. Rather than brute division, he sees lines of connection between the two parts that render the entire work cohesive. Grøn's observation is important because it emphasizes the fact that SUD is a unified text and should not be split into two only minimally related parts. There are, in fact, lines of connection between the two parts that should be traced. It is equally important, however, not to fall off the other side of the horse by overemphasizing the unity of the text at the expense of its distinct elements. As discussed above, the god-talk Anti-Climacus includes in part one is indeterminate. It is not dependent on revealed theology but falls within the scope of what is accessible to the Socratic-human understanding. Part two draws from Christian scripture as an epistemic source of authority.

50 (Roberts 2001, p. 136).

51 (Kierkegaard 1983, p. 77).

52 (Kierkegaard 1983, p. 95).

53 (Kierkegaard 1983, p. 79). 
Knut Alfsvåg describes the strategic movement of SUD in a way that preserves both the text's unity and its diversity. He argues that part one is an attempt to present the Christian message in a way that makes sense for unbelievers by drawing from the frameworks accessible to them. He writes:

For Anti-Climacus ... the story of Christ as the manifestation of the truly human opens the possibility of a new way of applying the Socratic method. If Christ is the true human and faith is the only way of appropriating this truth, lack of faith will prevent the realization of the truly human in a way that supposedly is psychologically explorable. The approach chosen in The Sickness unto Death is thus a kind of via negative through which the author explores the psychological consequences of faith's absence in the hope of evoking recognition in his readers, thus finding an indirect route to showing the relevance of a Christ-centered anthropology. ${ }^{54}$

There is a clear logical progression to SUD, one that meets the unbelieving reader where they are. By using the epistemic resources available to them, Anti-Climacus helps the reader see themself as a contingent rather than a self-positing being. Furthermore, he helps them recognize their experience of despair as directly related to a mis-relation between them and the power that establishes them. The progression of the text indicates that Anti-Climacus hopes to accompany the reader on a deeper consideration of these matters through revealed theology. Thus, while he respects the distinction between what is available to human understanding and what is only accessible through revealed theology, it is clear the author has a higher theological aim that directs the text as a whole.

\section{Breakthrough}

You know you have crossed the Rubicon between philosophy and theology when you arrive at offense. It is one thing for the Fichtean self to recognize that it was mistaken - that it is not self-positing after all but is contingent on a higher power. It is quite another for it to realize it is a sinner. According to Anti-Climacus:

The possibility of offense lies in this: There must be a revelation from God to teach man what sin is and how deeply it is rooted. The natural man, the pagan, thinks like this: "All right, I admit that I have not understood everything in heaven and on earth. If there has to be a revelation, then let it teach us about heavenly things; but it is most unreasonable that there should be a revelation informing us what sin is. I do not pretend to be perfect, far from it; nevertheless, I do know and am willing to admit how far from perfect I am. Should I, then, not know what sin is?" But Christianity replies: No, that is what you know least of all, how far from perfect you are and what sin is-Note that in this sense, looked at from the Christian point of view, sin is indeed ignorance: It is ignorance of what sin is. ${ }^{55}$

Revelation tells the self that it is a sinner, an offense to a holy God. The self, in turn, is offended by the notion that it is an offense. It is easy to overcome a mistake, but how is the self to deal with sin?

Most people think of sin as a specific list of vices, but Anti-Climacus says the root of every apparent vice is the self's personal desire to usurp God and instate itself as the Absolute Self. He writes:

A definition of sin can never be too spiritual (unless it becomes so spiritual that it abolishes $\sin$ ), for $\sin$ is specifically a qualification of spirit. Furthermore, why is it assumed to be too spiritual? Because it does not mention murder, stealing, fornication, etc.? But does it not speak of these things? Are not they also self-willfulness against God, a disobedience that defies his commandments? On the other hand, if in considering sin we mention only such sins, we so easily forget that, humanly speaking, all such things may be quite in order up to a point, and yet one's whole life may be sin, the familiar kind of sin: the glittering vices, the

54 (Alfsvåg 2014).

55 (Kierkegaard 1983, p. 96). 
self-willfulness that either in spiritlessness or with effrontery goes on being or wants to be ignorant of the human self's far, far deeper obligation in obedience to God with regard to its every clandestine despair and thought, with regard to its readiness to hear and understand and its willingness to follow every least hint from God as to his will for the self. The sins of the flesh are the self-willfulness of the lower self, but how often is not one devil driven out with the devil's help and the last condition becomes worse than the first. ${ }^{56}$

Continuing his thought, Anti-Climacus says that a Pharisee is one who "in despair manages a sort of legal righteousness" by avoiding surface-level sins while, deep down, continuing to assert itself as its own establishing power. It is possible for the self to maintain outward morality while still refusing to rest transparently in the power that establishes it. Through self-justification, the Pharisee retains its self-mastery rather than surrendering to God as its master.

Anti-Climacus then describes the unrepentant sinner as infinitely separated from God "by the most chasmic qualitative abyss. ${ }^{\prime 57}$ In fact, he says there is no infinite, qualitative difference so great as that between an unrepentant sinner and a holy God:

The teaching about sin—-that you and I are sinners—a teaching that unconditionally spits up "the crowd," confirms the qualitative difference between God and man more radically than ever before, for again, only God can do this; sin is indeed: before God. In no way is a man so different from God as in this, that he, and that means every man, is a sinner, and is that "before God," whereby the opposites are kept together in a double sense: they are held together, they are not allowed to go away from each other, but by being held together in this way the difference show up all the more sharply, just as when two colors are held together, opposita juxta se posita magis illucesunt [the opposites appear more clearly by juxtaposition]. ${ }^{58}$

Sin severs the God-man relationship to the extent that, as Torrance says, "there is 'nothing whatever' that human beings can do, in and of themselves, to relate themselves directly or positively to God. ${ }^{\prime \prime 9}$ In contrast to the Fichtean self, in which everything is contained within the immanence of the Absolute Self, Anti-Climacus emphasizes that the non-ego is not just ontologically distinct from the ego, it is infinitely, qualitatively, different from it.

Some scholars have concluded that the Infinite Qualitative Difference (IQD) is exclusively a result of sin. For example, Deede claims, "The difference between God and man, then, arises because of sin, which in turn creates the possibility for the mis-relation that is at the root of despair." ${ }^{\prime \prime 0}$ She maintains that God "became a man in order to overcome the infinite qualitative difference between man and God through the forgiveness of sins." ${ }^{61}$ This claim does not accord with Anti-Climacus's logic in Sickness unto Death. The problem with the self is not that it is unable to achieve the perfect synthesis of the binary opposites without assistance from God. As discussed above, self's first-order relation is

56 (Kierkegaard 1983, p. 96).

57 (Kierkegaard 1983, p. 122). Torrance draws a helpful distinction in Kierkegaard's authorship between sin-consciousness and guilt-consciousness. He writes, "[Sin-consciousness] leads a person to turn away from her proud autonomous existence by being drawn into a new life in relationship with God: a life that does not find fulfillment in individual self-perfection before God but rather in a humble life of relationship with God, in which a person becomes perfect. The latter, by contrast, only serves to alienate a person from God. Whereas guilt-consciousness turns a person inward to dwell on her error, sin-consciousness turns a person outward to God such that her error is dealt with. Unlike guilt-consciousness, sin-consciousness does not serve to compound an individual's sense of existential failure, and the attendant anxiety and despair. Rather, it alerts a person to the fact that she exists in a manner that is incommensurate with the way in which God created her to exist." (Torrance 2016, pp. 110-11). Sin-consciousness leads the self to turn to Christ for forgiveness. Guilt-consciousness leads the self to despair over forgiveness or to conclude that forgiveness is impossible. The guilt-conscious self decides to remain in its state of despair (sin). Since its relationship with God is the criterion for a healthy self, this self resigns itself to impoverished selfhood. (Kierkegaard 1983, pp. 121-22).

59 (Torrance 2016, p. 33).

60 (Deede 2003, p. 33).

61 (Deede 2003, p. 36) 
distorted because its more fundamental God-relation is broken due to the self's quest for self-mastery. Thus, it is not the infinite qualitative difference between God and man that is the problem, but man's desire to overcome that distance. Christ was sent to atone for sin "as completely as if it were drowned in the sea, ${ }^{\prime \prime 2}$ to stand in the space of the infinite qualitative difference not to collapse it but to mediate it. As the mediator, he does not overcome the space of the IQD but stands across it, allowing God and man to once again be in relationship with one another as infinitely qualitatively different beings. Christ's mediation prevents the difference from being either alienating or annihilating. He achieves unity without destroying difference. Because of his redemptive work, the infinite qualitative difference is restored a gracious space of encounter. As Anti-Climacus masterfully puts it:

No teaching on earth has ever really brought God and man so close together as Christianity, nor can any do so, for only God himself can do that, and any human fabrication remains just a dream, a precarious delusion. But neither has any teaching ever protected itself so painstakingly against the most dreadful of all blasphemies, that after God has taken this step it should be taken in vain, as if it all merges into one-God and man-never has any teaching been protected in the same way as Christianity, which protects itself by means of the offense. ${ }^{63}$

Kierkegaard uses the conceptual capital provided by revealed theology to break open philosophies of immanence, like Fichte's, without falling into a philosophy of fragmentation. Christ is the mediator who does not synthesize the Creator and the creation in a higher unity, but who holds all (distinct) things together. Bringing the picture more clearly into focus, the self that rests in the power that establishes it is one that repents of its pretension of self-mastery, surrenders its attempts of self-justification, and embraces the offense of the cross.

\section{A New and Better Self}

Anti-Climacus provides a lucid description of what an unhealthy self looks like. Thankfully, this state does not have to be a permanent one. The self that embraces Christ as its mediator through faith has its relationship with God restored and cured of its despair. What remains to be seen is what this new, healthy self looks like. The final pages of SUD are dedicated to such a description.

While German Idealism speaks of a spiritual ascent, a reunification with the absolute, Anti-Climacus specifies that the Christian is not someone who has overcome the infinite qualitative difference, but someone who guards it:

Christianity teaches that everything essentially Christian depends solely upon faith; therefore it wants to be precisely a Socratic, God-fearing ignorance, which by means of ignorance guards faith against speculation, keeping watch so that the gulf of qualitative difference between God and man may be maintained as it is in the paradox and faith, so that God and man do not, even more dreadfully than ever in paganism, do not merge in some way, philosophice, poetice, etc., into one-in the system. ${ }^{64}$

Anti-Climacus says that Socrates's God-fearing ignorance "was the Greek version of the Jewish saying: The fear of the Lord is the beginning of Wisdom." ${ }^{\prime 65}$ For the self who looks to Christ as its mediator, this fear is not horrifying and alienating. Rather, it is what Kierkegaard describes as law that governs the God-man relationship. The Christian who fears the Lord recognizes who it is in comparison to who God is. It is the finite creation; God is the infinite Creator. It is the servant; God is

\footnotetext{
(Kierkegaard 1983, p. 100).

3 (Kierkegaard 1983, p. 117). Note: by "the offense," Anti-Climacus is referring to Christ.

(Kierkegaard 1983, p. 99).

5 (Kierkegaard 1983, p. 99).
} 
the master. It is the forgiven; God is the forgiver. ${ }^{66}$ The self that willfully forgets this fear, this respect for the space of difference, is called a fool. The self that orients itself in light of this law governing the God-man relation is called wise. The wise self therefore keeps watch for any attempt to return to the delusion of self-positing and continually embraces its identity as a created being.

What does it mean for the wise self to rest transparently in the power that establishes it? Does it become see-through and barely-there? Would it not have less identity as a self, not more? Paradoxically, says Anti-Climacus, "Despair is intensified in relation to the consciousness of the self, but the self is intensified in relation to the criterion for the self, infinitely when God is the criterion. In fact, the greater the conception of God, the more self there is; the more self, the greater the conception of God." ${ }^{\prime \prime 7}$ Hence, the more the self embraces its contingency by resting transparently in God, the more concrete, palpable actuality it has. He exclaims, "And what infinite reality [Realitet] the self gains by being conscious of existing before God, by becoming a human self whose criterion is God!"68 Anti-Climacus pushes this truth even further as he progresses in his text. After discussing Christ's provision for forgiveness of sin, he presents the fullest expression of the theological self:

A self directly before Christ is a self intensified by the inordinate concession from God, intensified by the inordinate accent that falls upon it because God allowed himself to be born, become man, suffer, and die also for the sake of this self. As stated previously, the greater the conception of God, the more self; so it holds true here: the greater the conception of Christ, the more self. ${ }^{69}$

The true self is not just posited, it is loved. It was not just a created, it was redeemed at the highest price. It rests transparently not on a power that annihilates it but on one who saves it. Thus, the paradox holds: the more Christ, the more self.

\section{Conclusions}

According to SUD, theology and phenomenology, in a sense, do make two. Theology is not phenomenology, and phenomenology is not theology. They are qualitatively different disciplines that appeal to variant sources of authority. Nonetheless, they need not be alienated from each other, as presence of one does not necessarily demand the annihilation of the other. The difference between the two should be understood not as proof of their incompatibility but as the possibility of encounter. According to Falque, the aim of New Phenomenology is not to turn philosophers into theologians, but to allow theology to push beyond the limits of phenomenology and open up new modes of appearing. Theology transforms normal phenomenological vision, allowing it to see what otherwise could not have been seen. Falque writes:

As the philosopher and the theologian cross the Rubicon, they will have no choice in passing each other but to let themselves be transformed-each one by the other. The first will teach the second about the human journey. The second will make the first see that he cannot refuse to open himself-upon a decision of course-to the transcendence of the One who comes to "metamorphose" everything ... Working neither in pure opposition nor in simple complementary-and even less in competition, the two disciplines present themselves and articulate a discourse according to a common ascesis or spiritual exercise $\ldots{ }^{70}$

66 According to Anti-Climacus, "there is one way in which man could never in all eternity come to be like God: in forgiving sins" (Kierkegaard 1983, p. 122). The self never becomes its own justifier, the one who forgives itself. Rather, it is always the recipient of God's forgiveness.

67 (Kierkegaard 1983, p. 80).

68 (Kierkegaard 1983, p. 79).

69 (Kierkegaard 1983, pp. 113-14).

70 (Falque 2016, pp. 151-52). 
Anti-Climacus begins Sickness unto Death by casting a similar vision for philosophy, one where both philosophy and theology exist for part of a larger goal: edification. He writes:

Many will find the form of this "exposition" strange; it may seem to them too rigorous to be upbuilding and too upbuilding to be rigorously scholarly. As far as the latter is concerned, I have no opinion. As to the former, I beg to differ; if it were true that it is too rigorous to be upbuilding, I would consider it a fault.... From the Christian point of view, everything, indeed everything, ought to serve for upbuilding ... Everything essentially Christian must have in its presentation a resemblance to the way a physician speaks at the sickbed; even if only medical experts understand it, it must never be forgotten that the situation is the bedside of a sick person. It is precisely Christianity's relation to life (in contrast to scholarly distance from life) or the ethical aspect of Christianity that is upbuilding, and the mode of presentation, however rigorous it may be otherwise, is completely different, qualitatively different, from the kind of scienticity and scholarliness that is "indifferent". ${ }^{71}$

Anti-Climacus's description braves the prohibition separating philosophy, which is aimed at rigor, and theology, which is aimed at spiritual edification. He refuses the assumption that theology contaminates philosophy or that philosophy must disregard theology. Instead, both disciplines should be appropriately employed for the purpose of edification. The image of the doctor working at a sickbed should capture the imagination of both the theologian and the philosopher, uniting them in a higher calling and inspiring them to relate more, not less.

New Phenomenologists have devoted themselves to proving the maxim "the more we theologize, the better we philosophize." However, they are not the first to open up phenomenological analysis with the resources of theology. The work of a nineteenth-century Danish philosopher is a mature example of precisely what New Phenomenology aims to accomplish. Far from being destructive or contaminating, drawing from a theological archive opens up new possibilities and turns dead ends into new roads.

Conflicts of Interest: The author declares no conflicts of interest.

\section{References}

Alfsvåg, Knut. 2014. In Search of the Self's Grounding Power. International Journal of Systematic Theology 16: 376-77.

Beiser, Frederick. 1987. The Fate of Reason: German Philosophy from Kant to Fichte. Cambridge: Harvard University Press.

Beiser, Frederick. 2008. German Idealism: The Struggle against Subjectivism. Cambridge: Harvard University Press. Breazeale, Daniel. 1993. Fichte and Shelling: The Jena Period. In Routledge History of Philosophy: Volume VI: The Age of German Idealism. Edited by Robert C. Solomon and Kathleen M. Higgins. London: Routledge.

Come, Arnold. 1998. Kierkegaard's Method: Does He Have One? Kierkegaardiana 14: 14-28.

Copleston, Friedrich. 1965. History of Philosophy. New York: Doubleday Dell Publishing, vol. 7.

Deede, Kristen. 2003. The Infinite Qualitative Difference: Sin, the Self, and Revelation in the Thought of Søren Kierkegaard. International Journal for Philosophy of Religion 53: 25-48. [CrossRef]

Elrod, John W. 1975. Being and Existence in Kierkegaard's Pseudonymous Works. Princeton: Princeton University Press. Falque, Emmanuel. 2016. Crossing the Rubicon: The Borderlands of Philosophy and Theology. Translated by Reuben Shank. New York: Fordham University.

Fichte, Johann Gottlieb. 1969. On the Foundation of Our Belief in a Divine Government of the World. Translated by Paul Edwards. In Nineteenth-Century Philosophy. Edited by Patrick Gardiner. New York: Free Press.

Fichte, Johann Gottlieb. 1982. The Science of Knowledge. Edited and translated by Peter Heath and John Lachs. Cambridge: Cambridge University.

71 (Kierkegaard 1983, p. 5). 
Fichte, Johann Gottlieb. 1993. Fichte: Early Philosophical Writings. Translated and Edited by Daniel Breazeale. Ithaca: Cornell University Press.

Grøn, Arne. 1997. The Relation Between Part One and Part Two. In The Sickness Unto Death. Kierkegaard Studies Yearbook 1997. Edited by Neils Jorgen Cappelorn and Hermann Deuser. New York: Walter de Gruyter.

Hanson, Jeffrey, ed. 2010. Kierkegaard as Phenomenologist: An Experiment. Evanston: Northwestern University Press. Henrich, Dieter. 2003. Between Kant and Hegel: Lectures on German Idealism. Cambridge: Harvard University Press. Hicky, Lance P. 2004. Fichte's Critique of Dogmatism: The Modern Parallel. The Philosophical Forum 35: 65-80. [CrossRef]

Hün, Lore, and Philipp Schwab. 2013. Kierkegaard and German Idealism. In The Oxford Handbook of Kierkegaard. Edited by John Lippitt and George Pattison. Oxford: Oxford University Press.

Janicaud, Dominique. 2000. Phenomenology and the "Theological Turn". Translated by Bernard G. Prusak. New York: Fordham University.

Kangas, David. 2007. J.G. Fichte. In Kierkegaard and His German Contemporaries: Tome 1: Philosophy. Edited by Jon Stewart. Burlington: Ashgate.

Kierkegaard, Søren. 1983. The Sickness unto Death. Translated by Howard V. Hong, and Edna H. Hong. Princeton: Princeton University Press.

Klee, Louis. 2017. The Politics of Selfhood with Constant Reference to Kierkegaard. Kierkegaard Studies Yearbook 2017: 59-78. [CrossRef]

Lacoste, Jean Yves. 2018. The Appearing of God. Translated by Oliver O'Donovan. Oxford: Oxford University Press. Loncar, Samuel. 2011. From Jena to Copenhagen: Kierkegaard's Relations to German Idealism and the Critique of Autonomy in The Sickness Unto Death. Religious Studies 47: 201-16. [CrossRef]

Lumsden, Simon. 2014. Hegel, Heidegger, and the Post-Structuralists. New York: Columbia University Press.

Lundsgaard-Leth, Kresten. 2018. Recognition, Self-Recognition, and God: An Interpretation of Sickness unto Death as an Existential Theory of Self-Recognition. Kierkegaard Studies Yearbook 23: 125-54. [CrossRef]

Martin, Wayne. 1997. Idealism and Objectivity: Understanding Fichte's Jena Project. Stanford: Stanford University Press.

Neuhouser, Frederick. 1990. Fichte's Theory of Subjectivity. Cambridge: Cambridge University.

Pippin, Robert. 2000. Fichte's Alleged Subjective, Psychological, One-Sided Realism. In The Reception of Kant's Critical Philosophy: Fichte, Shelling, and Hegel. Edited by Sally Sedgwick. Cambridge: Cambridge University Press.

Roberts, Robert C. 2001. The Grammar of Sin and the Conceptual Unity of The Sickness unto Death. In International Kierkegaard Commentary: The Sickness unto Death. Edited by Robert Perkins. Macon: Mercer University Press.

Schaub, Edward L. 1912. Hegel's Criticisms of Fichte's Subjectivism. The Philosophical Review 21: 566-84. [CrossRef]

Simmons, J. Aaron, and Bruce Ellis Benson. 2013. The New Phenomenology: A Philosophical Introduction. London: Bloomsbury.

Stewart, Jon. 1997. "Kierkegaard's phenomenology of despair in Sickness unto Death". Kierkegaard Studies Yearbook 1997: 117-43. [CrossRef]

Torrance, Andrew. 2016. The Freedom to Become a Christian: A Kierkegaardian Account of Human Transformation. London: T\&T Clark.

(C) 2019 by the author. Licensee MDPI, Basel, Switzerland. This article is an open access article distributed under the terms and conditions of the Creative Commons Attribution (CC BY) license (http://creativecommons.org/licenses/by/4.0/). 